\title{
Spectacle and the Singularity: Debord and the 'Autonomous Movement of Non-Life' in Digital Capitalism
}

\author{
Clayton Rosati
}

\begin{abstract}
'Thus it becomes - money. 'Illi unum consilium habent et virtutem et potestatem suam bestiae tradunt. Et ne quis possit emere aut vendere, nisi qui habet characterem aut nomen bestiae aut numerum nominis ejus.' (Apocalypse.)'-Karl Marx, Capital, I, 1867. ${ }^{1}$
\end{abstract}

\section{Digital Capitalism and Apocalypse}

The spectacular character of technology in capitalist society, which has always seemed to be a force unto itself, has reached new heights in recent years and demands that we contemplate the self-movement of objects we make. In May 2014, a group of renowned physicists, including Stephen Hawking, did an unusual thing among their lot: they wrote a review of a Hollywood blockbusterMorgan Freeman and Johnny Depp's, Transcendence. In it, Hawking, et al. warn of the dangers of artificial intelligence (AI) and what has come to be known

How to cite this book chapter:

Rosati, C. 2017. Spectacle and the Singularity: Debord and the 'Autonomous Movement of Non-Life' in Digital Capitalism. In: Briziarelli, M. and Armano, E. (eds.). The Spectacle 2.0: Reading Debord in the Context of Digital Capitalism. Pp. 95-117. London: University of Westminster Press. DOI: https://doi.org/ 10.16997/book11.f. License: CC-BY-NC-ND 4.0 
as the 'Singularity' - uncontrollable technological self-enhancement. The scientists describe, in the most reasonable terms, a potential digital apocalypse:

So, facing possible futures of incalculable benefits and risks, the experts are surely doing everything possible to ensure the best outcome, right? Wrong. If a superior alien civilisation sent us a message saying, 'We'll arrive in a few decades,' would we just reply, 'OK, call us when you get here - we'll leave the lights on'? Probably not - but this is more or less what is happening with AI. Although we are facing potentially the best or worst thing to happen to humanity in history, little serious research is devoted to these issues outside non-profit institutes... All of us should ask ourselves what we can do now to improve the chances of reaping the benefits and avoiding the risks (Hawking, et al. 1 May 2014).

More alarmist is a BBC story from the following December titled, 'Stephen Hawking warns artificial intelligence could end mankind', in which Hawking is quoted as saying: 'Humans, who are limited by slow biological evolution, couldn't compete, and would be superseded.' And, in a tabloid Mirror story, Logan Streondj, 'a Canadian tech guru and sci-fi writer' speculates about the potential Terminator-style war between machines and humans (Hamill 1 July 2016). To many, the Singularity represents the coming obsolescence of human beings and their liquidation at the hand of their own creations.

Another version of techno-apocalypse puts human conflict back at its centre. Strangely more alarming (because it seems less far-fetched), the Independent (2016) reported that because of AI and nukes, 'Future war with Russia or China would be 'extremely lethal and fast', US generals warn'. In this case, we can see more clearly how technologies become mediations of and pressures on existing social conditions, in this case reviving hibernating Cold War panic spasms in the process. Whether Terminator or War Games, the last three years has seen its share of robot apocalypse press. Most of the ensuing debate between the AI optimists and doomsday preppers revolves around these scenarios: humans on a seemingly-avoidable-yet-inevitable course toward their own extinction via technology.

A recent Vice article sees it slightly differently. Thinking of the optimists' best-case scenario they ask: 'what if machines take over the world in a good way? No more punching the clock; instead, artificial intelligence would do the dirty work, and people would be free to paint and climb mountains and perform one-man shows about being raised by robots' (Wagstaff 25 April 2016). But even this ends badly. Drawing on Tim Wu's critique of what he calls 'the sofalarity', they find pessimism in this utopia: 'Most people remember the Pixar film WALL-E for the adorable robot love story, but it also contains a dystopian vision of humanity. Human beings suck down soft drinks while sitting in hovering recliners, from which they chat on video screens and watch ads for products from a company called 'Buy n Large.' Imagined within our current 
consumer economy, Vice argues that the apocalypse is not 'that the Cylons will destroy humanity; it's that we won't be able to pry ourselves off the couch, Portlandia-style, while watching the Cylons on Battlestar Galactica' (Wagstaff 25 April 2016). ${ }^{2}$ Even as work disappears, the consumption demanded by our economy persists. Alas, it really is easier to imagine the end of the world than the end of capitalism.

All these scenarios represent a crucial set of constitutive tensions within digital capitalism: between its violence and its engrossing pleasure (including the pleasure of violence), between its extraordinary abundance and its pronounced austerity and struggle for resources, between its unparalleled liberation of human communication and its profound movement towards authoritarianism, between its clear scientific capacity to transform nature for human benefit and its oppressive sense of inevitable apocalypse. But the speculations about AI also take the present social context for granted, as the natural - rather than political - environment in which AI and all machines are developed and utilized. From the Singularity to the 'Sofalarity', the extent to which the drama of digital apocalypse is the logical conclusion of class society (including its constitutive drives towards absolute social efficiency and fantasies of master races) remains a question unasked and presents us with a moment to interrogate not technology but the politics of autonomous objects and alienation in capitalist life.

Of course, an attack of the Cylons was not at all what Marx had in mind in his many quips about the abuses of living labour by 'dead labour', his euphemism for machines. Neither is it what he meant in his descriptions of capital as a live monster' that enslaves and torments its producers. But the AI panic is a useful way into thinking through the capitalist mode of production and its unity of productive forces and social norms of production. Virtually the only mention of capitalism in the context of the development and future of AI are in the many reports of the technologies, promises for future 'ROI' - return on investments. ${ }^{3}$ In these contexts, Guy Debord's 1967 manifesto, The Society of the Spectacle (SOS) can contribute to a critique of digital capitalism, the latest permutation of what he calls 'the autocratic reign of the market economy' $(2011,2)$. Few have so profoundly captured, condensed, and adapted the Marxian project. Specifically, Debord's notion of 'the autonomous movement of non-life' offers us an important lens to understand contemporary capitalism and to find new ways of understanding 'spectacle' in the process (1995, \#2).

This short essay explores what many call the rise of the machines in the context of capitalism's tendency towards impoverishment, autocracy, and war. And, for our world, autonomous machines and panics about the Singularity are crucial elements of the contemporary spectacle. The central struggle of digital capitalism is not (yet) between machines and humans but between social life and its forms of mediation, which already - and have for so long subjugate humans as they provide for their liberation. And, as the AI panic brings into focus, the fate of the world depends on the outcome of that struggle. Below I will discuss how Debord's spectacle and with it his reference to objects 
and especially images as 'autonomous' help us better theorize the rise of the machines and digital capitalism. To do this, we must explore the spectacle, not only as a euphemism for mass media, but as capital that demands the autocracy of property, the creation of surplus populations, and, which grows for itself, not for the life of the society that creates it. Subsequently, we will explore Debord's critical engagement with the politics of human obsolecense and 'surplus' people and how this can be extended to AI, the rise of the machines, the Singularity, or some other post-human apocalypse. Lastly, this essay explores the struggle against this bleak future through Debord's celebration of the revolutionary 'worker's council' and its contemporary quandaries of double agents, bots and trolls. This essay's reading of Debord's spectacle approaches its concepts (and puzzles) through the Marxian tradition, against capitalism entirely, not just its media forms. Most importantly, the essay focuses on aspects of Debord's critique that urge us, within the anti-capitalist struggle, to move beyond 'who is producing value' to 'who controls the economy', and then beyond that to a principle of 'optimal development' ${ }^{4}$ for all - a principle of inclusion, not a scenario of extinction. Extinction by Cylon apocalypse is, in many ways, the pinnacle of the spectacle in a sense missed by the Sofalarity. But, to understand why, we must dive deeper into Debord's critique and the spectacle itself.

\section{Spectacular Theory and the 'Autonomous Image'}

Narratives of the Cylon apocalypse shock many of our conversations about digital capitalism - usually regarding information access, the transformation of privacy, and so forth - by pulling them back to the raw exercise of power. Most often, the spectacle is described in terms of distraction or 'bread and circuses.' In this context, the spectacle is the bearer of the 'Sofalarity', not the Terminator or Cylon apocalypse. ${ }^{5}$ Debord's revolutionary, anti-capitalist manifesto for human self-determination is most often seen as an analysis of distraction, bread and circuses, or propaganda and simple 'false consciousness. ${ }^{6}$ Frequently, in fact, it seems as if readers never make it past the second chapter to his explicit critiques of anarchism, Stalinism, and the like. This is part of a bigger problem in critical theory, a skewed understanding of key concepts like 'reification', 'fetishism of commodities', and 'capital', such that they are unequipped to be read towards a holistic, anti-capitalist struggle for freedom or optimal development. Often, siloed media-centric readings turn Debord's critique of capitalism into a problem of perspective or reductive mesmerism. But, for a prying reader, the SOS contains a far more sweeping - and militant - critique and proposition, which are often missed in spectacular fashion. Such flattened readings of a Marxian critique of 'ideology', must be put in conversation with the more tangible and practical-political conditions also described in the SOS and in Debord's other work. This flattening is endemic in much of the interpretation of SOS, where the problem of the spectacle is a problem of thought, of ignorance, of 
individual practice. Often, the spectacle becomes a caricature of the Marxian paradigm, read through a caricature of the Frankfurt School's critique of consumer culture.

Take, for example, these comments from a 2012 episode of The Guardian's 'Big Ideas' podcast (Walker, 2012): 'If we live in the age of media saturation, and a sense in which even the most intimate parts of our lives have partly been commodified, [...] sold back to us...even the way that we relate to each other, our very understanding of social life and so on, has been so commodified that it's no longer authentic, it's not our own work, it's something that we look at in the spectacle and we sort of draw into our own existences and that's the level of alienation that [Debord's] talking about.' Beyond begging what it means to be 'commodified' or 'authentic', this presents a one-dimensional reading of the Marxian platitudes that 'the ideas of the ruling class are in every epoch the ruling ideas' or the economic 'base' determines the cultural 'superstructure'. Here, the spectacle is something like a hypodermic needle, injecting us with ideology or some Matrix-style brainwash into an otherwise pure and sovereign individual. ${ }^{7}$ And, subsequently, resistance to the dominance of images and loss of real lived experience is theorized in the most tragic ways, read mostly through the dérive and détournement-as carnival against capital.

To be sure, Debord's spectacle must be updated to include Internet propaganda bots, consumer data, and all the new armies of political-economic double agents, leakers, false leakers, and hackers. But, further, what happens when ideologies of 'commodification' become autonomous, Cylons, bent on human extinction? ${ }^{8}$ To a large extent this 'false consciousness' reading of spectacle maps onto a truncated (but entrenched) reading of the 'fetishism of commodities', understood simply as either an irrational attachment to objects or a veil that shrouds the real relations of production and exploitation. Simon During combines both, for instance, here in editorial comments on Raymond Williams:

In a metaphor which goes back to Marx's belief that capitalism makes commodities 'fetishes', for Williams advertising is 'magic' because it transforms commodities into glamorous signifiers (turning a car into a sign of masculinity, for instance) and these signifiers present an imaginary, in the sense of unreal, world. Most of all, capitalism makes us forget how much work and suffering went into the production of commodities $(2007,411){ }^{9}$

Here, the focus on media consumption misses an analysis of what is essential in capitalist society itself and what drives its development into scarcity, famine, war, and perhaps apocalypse. Yet, there are other features of the SOS, namely its (coded or not) engagement with the material conditions of the Cold War, of capital and money, of time and urban planning, and the techniques of selfgovernment. In this section, we will explore specific tensions within the SOS itself. And, we will focus on a different reading of the spectacle, one attached to 
a crucial part of the Marxian tradition, reading 'images' through the analysis of the historical form of value (money and wages) and capital's self-movementthe 'live monster that is fruitful and multiplies' (Marx 2011, 217). It is here, in the 'autonomy' of objects, where an analysis of spectacle and AI apocalypse gets off the ground.

\subsection{From Fetish, to Reification, to 'The Autonomous Image'}

To get from Debord to the rise of the machines, we must carefully unpack the foundations of his spectacle. What is the relationship between spectacle and autonomous machines? In Thesis \# 2 of SOS, Debord presents us with an ambiguity. And, how we interpret it colours our reading of the rest of the book: 'The tendency toward the specialization of images-of-the-world finds its highest expression in the world of the autonomous image, where deceit deceives itself. The spectacle in its generality is a concrete inversion of life, and, as such, the autonomous movement of non-life' [my emphasis].

Moving forward, we encounter what seems like a friction between an intuitive reading of spectacle-as-mesmerism and much of what comes later. For instance, the wording of Theses \#3 and \#5 seem to rub against each other. In $\# 3$, Debord describes the spectacle as the 'locus of illusion and false consciousness.' Yet \#5 changes direction, opposing a reading simply of 'deliberate distortion' and demanding we instead contemplate the spectacle as a 'world view transformed into an objective force': 'The spectacle cannot be understood as an abuse of the world of vision, as a product of the techniques of mass dissemination of images. It is, rather, a Weltanschauung which has become actual, materially translated...' (\#5, emphasis mine). How should we interpret 'images' and 'mediation' in SOS?

If Debord is suggesting that the 'autonomous image' is made up of 'consumerist fantasies' that conquer our consciousness by their own volition, we have something quite problematic and analytically deflated by resistant consumption and readings. Or, maybe we simply write it off as poetry. Yet, Georg Lukács' influence on Debord's thinking is clear in his development of Marx's fetishism of commodities through the concept of 'reification' (see Jappe 1999). In this context, 'mediation' refers not to problems of thought alone but to the broader material context of the capitalist processes of production and exchange: 'mechanisation makes of [workers] isolated abstract atoms whose work no longer brings them together directly and organically; it becomes mediated to an increasing extent exclusively by the abstract laws of the mechanism which imprisons them' (Lukács 1972, 90). For Lukács, the separation of social activity and its mediation creates something qualitatively different than the sum of its constituent parts, 'man's own activity, his own labour becomes something objective and independent of him, something that controls him by virtue of an autonomy alien to man' $(1972,87)$. From the effects of the division of labour 
and mechanization, he explains the 'objective' and 'subjective' aspects of that 'autonomy' and its subjugation of social life. But, in the prevailing readings of the spectacle, we rarely get a sense of those constitutive 'objective' arrangements of things, those things that are both the product of and the limits and pressures on thought and consciousness - the matter and material arrangements of class struggle.

So, from Lukács, what other 'images' might Debord be picturing? Marx reminds us that 'every commodity is a symbol, since, in so far as it is value, it is only the material envelope of the human labour spent upon it' and money is the universal equivalent among them all (Marx 1992, 94). '[T] he spectacle is capital accumulated to the point where it becomes image' (\#34, emphasis original). More specifically, we might see the 'autonomous image' as a not-socoded reference to Marx's description of the 'self-expansion' of capital. In fact, the 'autonomous' movement of society's alienated products is Marx's extension and critique of Smith's and Ricardo's labour theories of value and his turning of Hegel's idealist progress of History on its head. Capital is not just wealth but, as David Harvey summarizes, 'value in motion' $(1982,71)$. For Marx, it is the (apparent) self-movement of commodities, congealed human labour, and thus, symbols of value that founds his critique: 'By turning his money into commodities that serve as the material elements of a new product, and as factors in the labour-process, by incorporating living labour with their dead substance, the capitalist at the same time converts value, i.e., past, materialised, and dead labour into capital, into value big with value, a live monster...' (Marx 2011, 217). If prevailing understandings of the spectacle tend to focus on people's captivation by media and entertainment, flattening that critique to media alone takes Debord's work out of the most important contributions of Marxian interrogations of political economy: the critique of capital's 'self-expansion'.

\section{2 'Another facet of money': Capital and Autocracy}

The most tepid of the AI debates focus on whether AI will create mass unemployment (Manjoo and Bowers 2011), much as previous forms of automation reduced the amount of necessary labor for early nineteenth century weaving (Marx 1992) or 1980s and 90s auto manufacturing. However, without getting deeper into Debord's critique of images and mediation, we cannot fully grasp why the Marxian project has always rejected automation as the cause of unemployment and its corollary immiseration. Marx's critical point was not simply that people created value through labour or even that people struggle over the surpluses of that labour. But, instead, part of what connects Marx's investigations, from his 1844 notebooks to Capital, Volume 3, is the revelation of how value becomes trapped in the commodity form. Thus, while we may find money across a long history of human activity, only within capitalism does it take on the particular function with wage-labour and interest-bearing capital to create 
the process that drives capital as a perpetual growth machine. Only within capitalism does the medium of exchange and its metamorphosis into commodities and back (+ interest) take on a purpose of its own: growth. In Debord's words:

The spectacle is another facet of money, which is the abstract general equivalent of all commodities. But whereas money in its familiar form has dominated society as the representation of universal equivalence, that is, of the exchangeability of diverse goods whose uses are not otherwise compatible, the spectacle in its full development is money's modern aspect; in the spectacle, the totality of the commodity world is visible in one piece, as the general equivalent of whatever society as a whole can be and do. The spectacle is money for contemplation only, for here the totality of use has already been bartered for the totality of abstract representation (\#49). ${ }^{10}$

Pushing past a focus only on media and distraction, the SOS pulls us deeper into the Marxian trajectory: 'As it accumulates, capital spreads out to the periphery, where it assumes the form of tangible objects. Society in its length and breadth becomes capital's faithful portrait' (\#50). The spectacle can be seen as both the prevailing phenomenal form of social activity and wealth embodied in money, interest and economic growth. And, while we might focus on who has more wealth or who is exploited in production, a less travelled path in this line of thinking is how the circulation of commodities as capital dominates collective social activity and its potential, even though we produce that process over and over. So, an era of unemployment, coinciding with intense automation and AI, is not caused by the technologies but by the prevailing form of value.

Marx's early observations on money, in his reading of James Mill, for instance, help put Debord's references into a context beyond mass media or commercial culture: 'The essence of money is not, in the first place, that property is alienated in it, but that the mediating activity or movement, the human, social act by which man's [sic] products mutually complement one another, is estranged from man and becomes the attribute of money, a material thing outside man.' Marx continues: 'Owing to this alien mediator-instead of man himself being the mediator for man-man regards his will, his activity and his relation to other men as a power independent of him and them. His slavery, therefore, reaches its peak' $(1975,212)$. If Debord follows Marx in this way, then his critique (and definition) of the spectacle - and with it, his references to 'passivity' and 'contemplation' - is not simply a question of society enthralled by advertising and consumerist messages but rather, society enslaved by the forms of its mutual exchange and made to serve its own product, capital. Emphatically, Marx expounds 'It is clear that this mediator now becomes a real God, for the mediator is the real power over what it mediates to me. Its cult becomes an end in itself' $(1975,212)$. In the spectacle, we can see this 'cult' of money as part of the lived experience of contemporary capitalism. Already, well before the age of 
Cylons and AI, objects dominate the social activity that creates them because of the forms that mediate creation.

\section{Pseudonature, or the Autonomous Image in Digital Capitalism}

If the spectacle, as a mediating image, is 'money for contemplation only', characterized by its 'autonomous movement', what is it as an element of digital capitalism, or for that matter, the constantly looming Cylon apocalypse? To capture a similar specificity, Georg Lukács explains: 'we must be quite clear in our minds that commodity fetishism is a specific problem of our age, the age of modern capitalism' $(1972,84)$. For Lukács capitalism is the historical epoch where the vast social interconnections are objectified and rationalized, 'reified. Here, 'the commodity become[s] crucial for the subjugation of men's consciousness to the forms in which this reification finds expression and for their attempts to comprehend the process or to rebel against its disastrous effects and liberate themselves from servitude to the 'second nature' so created' $(1972,86)$. This concept of nature, and servitude to it, are crucial to understanding Debord's spectacle. And, within capitalist 'second nature', the threat of human extinction from our own powers begins to take further shape. Debord argues that the expansion of economic power, the development of wage labour and the wealth it created solved the 'initial problem' of natural scarcity. But, this historical shift continually recreated the problem of survival at ever-higher levels:

Economic growth has liberated societies from the natural pressures that forced them into an immediate struggle for survival; but they have not yet been liberated from their liberator. The commodity's independence has spread to the entire economy it now dominates. This economy has transformed the world, but it has merely transformed it into a world dominated by the economy. The pseudonature within which human labour has become alienated demands that such labor remain forever in its service... (\#40).

Through the wage labour system, finance and interest-bearing capital, rent and the whole subsequent farce of hedge funds, and so on - all efforts to transcend this nature lead back to it; money like weather, determining our fortunes. And, in Lukács' words, this spectacle must have objective as well as subjective attributes. In the society of the spectacle, the state constantly represses self-rule what Hardt and Negri call the 'becoming-Prince of the multitude' (2011) through forms of legal servitude. But class power itself is only part of the story; for, the self-movement of commodities imprisons the poorest waste picker and the most well-meaning tech start up alike (see Birkbeck 1978). Like tainted soil, this second nature of compulsory commodity circulation only allows 
certain things to grow. So, when Debord exclaims that this 'pseudonature [...] demands that such labor remain forever in its service' and therefore ' $[t]$ he spectacle is not just the servant of pseudo-use - it is already, in itself, the pseudouse of life' he is not simply (or only) making a curmudgeonly statement about vapid pop music, movies or fashion but instead a very specific critique of reified society and human subservience to their own products via the forms that mediate production. This is as true in the digital epoch as it was in the preceding. If humans are to face subjugation or annihilation by machines, it will be due to this concrete pseudonature, which contains within it subjugation and seeds of annihilation. In the following sections, we will briefly explore four such seeds or 'moments' ${ }^{11}$ in the overall process of digital capital's expansion, which are part of the new nature built on the 'autonomous movement of non-life' in the context of artificial intelligence: rent, finance, commodity capital, and automation. In these moments of pseudonature and pseudo-use of life, the principle of producing scarcity within abundance shows us a pathway within digital capitalism towards a potential Cylon apocalypse.

\subsection{Digital Imperialism}

Debord's 'autonomous image' can apply in a most straightforward way to finance, a key moment in digital capital's autonomy. And perhaps we can find in Debord echoes of Lenin (1969), showing us that finance is crucial to the imperialist stage of capitalism. In SOS, the autonomous image can clearly be read through Marx when he suggests that finance and interest-bearing capital is a relationship of magnitudes, a relationship of the principal sum as a given value to itself as a self-expanding value, as a principal sum which has produced a surplus-value. And capital as such, as we have seen, assumes this form of a directly self-expanding value for all active capitalists, whether they operate on their own or borrowed capital' (Marx 1993, 515). The formula for interest-bearing capital (M-M') is the most fetishistic, in Marx's explanation, as money appears simply to grow on its own, and allow its owners - interested only in quantitative growth - to demand as much. But the chance workings of the market are often full of unacceptable inefficiencies. And, states (like organized crime) often try to rig circumstances in their favour. Debord explains in Comments on the Society of the Spectacle: 'It is always a mistake to try to explain something by opposing Mafia and state: they are never rivals. Theory easily verifies what all the rumors in practical life have all too easily shown. The Mafia is not an outsider in this world; it is perfectly at home. Indeed, in the integrated spectacle it stands as the model of all advanced commercial enterprises' $(2011,67)$. While Debord emphasizes the unity of the spectacle, one must also recognize the internal struggles (various Opium Wars), through which that unity advances. The extension of financial interests internationally has created an expansion of state espionage and protection rackets serving the autonomous image. Digital technology, often developed in the name of the war on terror - what 
Debord describes as the contemporary spectacle's only available enemy has been leveraged by governments in a war of all against all, ensuring continued unification within spectacular society. The US's NSA was recently exposed for a decade of using its post-9/11 signals intelligence apparatus for economic espionage in Germany, Brazil, France, and elsewhere.

It is not difficult to imagine the spectacular struggles to control the production of nature and impose pseudo-scarcity leading to AI-assisted (nuclear) war. As control of natural resources becomes crucial in the production of machines (including for war), and as national security can become linked to property holdings policed by other nation-states, war over mineral deposits and energy sources loom as ominously now as it did with United Fruit (US in Guatemala) and Anaconda Copper (US in Chile) did in the previous century. AI will develop, like the capitalist food and metals systems, around the politics of investments in key locations and the mechanisms of their defence. But, if acquiring resources is a struggle, converting those resources investments into revenue is as well.

\subsection{Autocratic Terrains}

$\mathrm{AI}$, as a tremendous force in production, contains the seeds of a crisis in consumption (demand) - how will companies justify making profits if goods and services cost nothing in labour to make? As with exchange of digital goods and services (entertainment, software, etc.) in the Internet era, control of the infrastructure (means) of both production and consumption will become even more deeply cutthroat, monopolistic, and extortionistic, based only in the historical and prevailing norms of ownership, in the autocracy of large-scale private property. In the current period, relations of rent provide us with a useful comparison to think about what will likely emerge with capitalist AI.

Debord does not discuss rent in SOS, but considering Debord's critique through a Marxian lens helps illustrate how the spectacle transforms our world in order to maintain human subjection to our own products. Rent is 'surplus profit' siphoned by a landlord (ground rent) or a specialized producer (monopoly rent). In digital capitalism's current relations of rent we can be rather literal about the spectacle's oppressive 'nature' by looking at aspects of the groundwork and infrastructures of the digital economy. On this second nature, digital capitals constantly construct new forms of pseudo-scarcity. For example, when the Dot-com bubble burst in the early 2000s it was in no small part due to the overproduction of fibre optic and storage infrastructure. Companies sank speculative capital into data centres and fibre with the intention of renting them, as digital landlords and tollbooth owners, to generate shareholder growth through the control of Internet traffic (Townsend 2003). When it became clear that capacity outpaced demand, we witnessed ostensibly the first real estate crisis of the new millennium (Townsend 2003). Like other real estate crises, financial speculation mediated the production of physical environments through the floating signifiers of stocks and paper claims to wealth. 
Debord's spectacle can be seen in how the promise of future revenue effectively imposed its own force on the literal shape of our world and its future uses. Even in overproduction there is underdevelopment. With AI, we can expect a similar investment in control of the terrain, the development of nature to serve capital's self-expansion. This can work in the inverse.

The spectacle moving as both rent and finance develops according to its own rules just as clearly in the forms of digital inequality throughout the country and the world. In rural Mississippi and other rural and urban parts of the US, massive digital deprivation exists, due to a lack of infrastructure (Crawford 2013; Eubanks 2015; Gilbert and Masucci 2011). Digital inequality is a persistent story and a crucial example of Debord's autonomous movement of capital. Because of the likely losses or unfavourable revenue prospects, Internet, TV, radio, and cellular providers intentionally underdevelop large swaths of the human community globally (Crawford 2013). And, those experiments in infrastructural penetration into poorer or less dense areas are often tainted by especially cynical quid pro quos, like Facebook's offer of 'free' limited Internet 'basics' to rural India, including Facebook. This resulted in protests demanding the full Internet, Net neutrality regulations, and a better offer from Google's 'Project Loon's' Wi-Fi balloons. But the private 'alien' powers, demanding returns on investments are at work in the regular flows of digital traffic. As most things in the neoliberal project that have been part of the fertile terrain for digital capitalism, Internet providers in the wealthiest places work to segment audiences and stratify access to this resource according to private preference and payment capacity, called 'throttling', 'blocking', and 'paid prioritization.' ${ }^{12}$ There is no natural scarcity here, only the limits imposed by owners of this pseudonature and the drives of its mediums of production and circulation. ${ }^{13}$ One must imagine the rise of the machines to be uneven, to be interested most in growing investments, and least in directly liberating the self-government of life in the world, particularly for those without money. But, no doubt, AI will increasingly be used to gouge everyone, prevent sharing, make resources artificially scarce, and impose autocratic authority over both production and consumption. Debord's spectacle can help us see his crucial conceptualization of inversion, vis-à-vis capital's drive to circulate, which confines and distorts social development. Underdevelopment is structured not (necessarily) out of malice but capital's drive for growth. This is not an unreal world but a world that 'really is topsy-turvy', a 'false' world (\#9). The rise of the capitalist machines will form this 'false' world not because machines are somehow 'artificial' or 'inauthentic' but because of their role in capital's inverted relationship to means and ends.

\subsection{AI, Wages and Consumption}

The emergent rise of the machines is occurring (and will) primarily to save labour costs, so long as capital's self-expansion is the prevailing condition of 
necessity in society. The massive force that artificial intelligence will unleash in production (supply), making goods historically easy to produce and requiring no wages (especially, as machines increasingly re/produce themselves), is potentially costless on the basis of human effort. But it will also, as such, create a crisis for a society accustomed to acquiring its subsistence from wage-labour. And the financial forces that sit behind the above infrastructural distortions of our social geography (that recently imposed expanding poverty and servitude in Greece and collapsed the world financial markets), and that will likely annihilate whole sectors of the labour market, are also drilling down to the individual. Like GoFundMe.com's 'personal fundraising campaigns', Kiva.org and other microfinance sites further embed and personalize capital. Debord's coded 'autonomous image' and its self-movement help us see the relationships between finance and wages. As money limits options for exchange and draws us deeper into wage relations, individuals and families may have more money and experience more deprivation simultaneously (Sen 2000).

Such limits haunt our attempts to resolve this subservience to the spectacle. As starvation threatens South Sudan, Somalia, North-east Nigeria, and Yemen - while Americans throw away half their produce and the world wastes a third of its food - a US-based organization, GiveDirectly, has developed an experiment for a universal wage in a Kenyan village of about 220 people. Using cellular phones and digital identification numbers, residents of the unnamed village will receive $\$ 22$ a month for 12 years. The expansion of wages of all sorts has quantitatively effected a supposed massive reduction of world poverty, celebrated by British Foreign Secretary Boris Johnson as the 'unadulterated triumph of what you might broadly call western values, technology, culture, and indeed western economic thinking.' Perhaps he is correct and what we have seen in the history of wage labour will no longer be true. Many other countries, including Canada, are also experimenting with universal wage policies. Or perhaps these new experiments only expand the very 'autonomous image' that subjugates social life, trapping it further in the money form of value, wage labour, and the exchange of fetishes within a global money cult, depriving access to other pathways of value and exchange. But, for Debord, the drive of this unification is not simply the combination of state and capital to extend the influence of private powers; it is instead the drive for the spectacle's self-expansion. With the rise of $\mathrm{AI}$, and its subsequent contradictions and crises, we can expect to see crypto-currencies and other new money-based forms proposed as potential resolutions to this inverted relationship.

\subsection{Consumer Data as Pseudonature}

In the dreaded 'Sofalarity' described by Tim Wu we see an aspect of this topsyturvy world that we can trace back to Keynesian subsidization of wages - life 
exists for the turnover of investments, for capital's expansion. The third key moment of this pseudonature is consumer data, part of commodity capital's costs of circulation, which now form a 'map identical to the territory it is representing' (\#31). The costs of circulation are what retailers and commodity sellers spend, in this case on marketing and research, to convert their wares back into money. Important critiques of consumer data and surveillance demonstrate how its collection and utilization rely on accumulation by dispossession (Thatcher, et al 2016), unpaid labour, coercion and exploitation (Andrejevic 2003; 2013). AI is currently and increasingly being developed to read consumers' minds, project their desires back to them, and capture them as consumers for capital's turnover. Debord pushes these critiques further to the core Marxian critique of capitalism. We have seen this spectacular process already at work in filters and profiles, which have over the last two decades, in increasingly granular ways, grouped consumers into psychographic 'tribes' and target populations (see Rosati 2012). This alienation of habits, preferences, fantasies, friendship and professional networks, and so on as private property ha notoriously bracketed our lives into bubbles (e.g. Sunstein 2017). But, those bubbles - turned echo chambers - represent the development of the individual as an identity, a natural essence. Here Debord's critique of capitalist nature extends to the use of machines in humans' crucial forms of selfproduction, which will likely advance as AI advances.

We can extend Lukács here: 'With the modern 'psychological' analysis of the work-process (in Taylorism) this rational mechanisation extends right into the worker's 'soul': even his psychological attributes are separated from his total personality and placed in opposition to it so as to facilitate their integration into specialised rational systems and their reduction to statistically viable concepts' $(1972,88)$. The spectacular issue is not simply that consumers love X deodorant brand or Y princess movies, but that the reinforcement of pleasures becomes an internal compass leading around other potential directions, aestheticizing desire, and removing it from conflict with other pathways. Pleasure or discomfort 'is not the necessary product of technical development seen as a natural development; rather it is part of the spectacle, 'the form which chooses its own technical content' among which we might count our 'souls' (\#24). Desire grows but it actualizes a false essence, grown in a false nature. ${ }^{14}$ And these forms of individuation are only part of the broader conditions of subjection within digital capitalism. Metrics of driving habits, exercise habits, work habits, personal health, etc., are increasingly leveraged against insurance claims, care coverage, and other means of linking cost with individual responsibilization. What Haraway calls 'informatics of domination' $(1991,161)$ produce a (Pavlovian) behavioral-austerity link, which is the soft-violence of what Marx critiques as 'so-called primitive accumulation' and 'original sin' among the political economists: via data, wealth becomes not about social processes but isolated individual choices. 


\subsection{Automation after Scarcity}

If, as much of the economic press (and an occasional physicist) has us worry, work disappears as a correlary to the development of AI, we must understand that this correlation is not its cause. All the above developments lead us back to Debord's problematization of economic productivity in automation, where all the previous conditions of self-movement converge at their highest tension, as most liberatory and most subjugating - freeing us from work without freeing us from wages. Neither Marx nor Debord could have anticipated the growth and intensity of automation in the digital age. My phone already knows the next word I want to text, it transcribes my voice, it reminds me to eat lunch, grade papers, call my grandma. This essay, thankfully, was automatically spellchecked - I would surely have to pay someone otherwise. Machines (as weaving machines or code) are labour-saving devices about which the Marxian tradition is, in fact, optimistic and Utopian. Debord's critique of the social forms of scarcity and 'augmented survival' that accompany capitalist abundance and productive capacity captures the frustration of potential abundance and Marx's Utopian spirit. The now-famous 'fragment on machines' in Marx's notebooks hint at a world liberated by machines, no longer subjugated by wage labour and the self-expansion of capital. From mobile apps to pernicious malware bots, we are all utilizing the digital productive forces to save labour. But, for Debord, we live not just in deprivation amid potential abundance (as with food), but also amid the spectacle's direction of the potential itself. Donna Haraway reminds us that machines are part of our nature, not a deformation of our essence. So, let us pose Vice's question again, 'what if machines take over the world in a good way?' Would we all be evicted, unemployed, and starving? Or, would we be doomed to the 'sofalarity', using our universal wage to binge-watch the Kardashians, eat $\mathrm{KFC}$, and drink sugary beverages? If robots have been programmed as agents of spectacle, for class society, and capital's self-expansion, certainly both seem plausible. Donna Haraway perhaps channels Debord's push towards the reversal of our inverted relationship to technology when she writes, 'The machine is not an it to be animated, worshipped, and dominated. The machine is us, our processes, an aspect of our embodiment. We can be responsible for machines; they do not dominate or threaten us. We are responsible for boundaries; we are they' (1991, 180). As Debord points out, the social conditions of life will determine the kinds of machines we build and how they mediate our relationships.

The above examples of how capital limits and pressures the development social life for the maintenance of class society help us understand the spectacle in a broader sense, as the subjugation of social life to its own products. Debord explains:

[t] he alienation of the spectator to the profit of the contemplated object (which is the result of his own unconscious activity) is expressed in the 
following way: the more he contemplates the less he lives; the more he accepts recognizing himself in the dominant images of need, the less he understands his own existence and his own desires. The externality of the spectacle in relation to the active man appears in the fact that his own gestures are no longer his but those of another who represents them to him...' (\#30).

To what extent can we find our non-false nature beyond the spectacle through the 'cyborg?' If we are to follow Debord, the struggle against the mediation of our lives within a self-expanding system is the only way. But, we seem to be losing that struggle.

\section{Malthus and the Cylon: AI, Obsolescence and Digital Capitalism}

We have examined the spectacle's subjugation of social life to its own products. Perhaps nothing exemplifies this better than the fear of the Singularity, AI's domination of humans and/or our species' extinction. In this section, we will explore this as a crucial extension of the spectacle and symptomatic aspect of digital capitalism. Its analysis is crucial to a Debordian conceptualization of this epoch. Extinction by AI is a projection of the most extreme pseudonature, where society becomes the waste products of its own activity. Humans become not simply poor or jobless but obsolete. This spectre is not completely new.

Obsolescence is perhaps a corollary to white supremacy, which has long been a Social Darwinist mythology at the heart of the capitalist project, ${ }^{15}$ along with the Eugenicists dreams of breeding an optimally efficient population, no longer burdened by the 'unfit'. Marx scathingly critiqued similar ideas by Thomas Malthus for imagining that humans - particularly in the case of poverty - were stuck with fixed resources and subject to the population limits and competition of other species, whereas it was rather capitalism that demanded and produced poverty (1992). This model of fixed environmentalism, a nature with surplus people, is the rotten heart of capitalist AI. In this Malthusian nature, life is only useful to the extent that it can be monetized; and, digital capitalism dreams of mathematical autocracy. To the extent that AI posits human extinction, it invokes a trajectory of thought in which economic logic rationalizes the exclusion, sterilization, cleansing, and subjugation of populations. I hope we find a politics against this false nature as a corollary to Debord's critique of the 'autonomous movement of non-life.

Post-60s era fiscal discipline, regimes of austerity, and vociferous privatization have produced surplus populations as a matter of principle-produce value or die. Digital capitalism, we must recall, grew up in the age of deindustrialization, deregulation, multinational monopolies, trickle-down economics and mass incarceration. This era has wasted life like no other. Emblematically, the 
US imprisons more human beings than any other nation. Largely accumulated by the 'War on Drugs', which allowed links between drug trafficking and US anti-Communism in Latin America, prisons are also an industry that bails out deindustrialized communities. America's bonded masses are in essence political-economic prisoners in this sense. While digital capitalism has created an abundance of new communicative forms with soaring stock IPOs, it has also been disposing of living people, from parks, city centres, public housing, or engaging in predatory policing. Beneath the 'autocracy' of capital, those with property rule and profit from the disappearance of others. In this environment where humans are always potential 'waste', it should be no surprise that we imagine a Cylon apocalypse. Democratized as digital capitalism appears, it pongs of autocracy, violence, and extinction. Through the spectacle, we can see the commodity form's old politics of servitude (\#40) extended to a new pseudonature of extinction - the ultimate expression of the 'autonomous movement of non-life'.

This false nature implies power and hierarchy. Debord writes of the Keynesian, industrial ' $60 \mathrm{~s}$, 'The oldest social specialization, the specialization of power, is at the root of the spectacle. The spectacle is thus a specialized activity which speaks for all the others. It is the diplomatic representation of hierarchic society to itself, where all other expression is banned. Here the most modern is also the most archaic' (\#23). We must be clear that this specialization of power has advanced. Certainly, this is evident in the softest ways with the legal assassination of Napster, tremendous intellectual property fortifications, digital rights management schemes, and other criminalizations of sharing. These are the soft side of digital capitalism's despotism, using state force to maintain the commodity form and its corollary private right to payment. But, it is also evident within police agencies spying on and disrupting leftist activists, infiltrating labour actions, and arresting journalists. In the struggle over that right, the 'autonomous movement of non-life' is clearly class struggle by another name. National leaders no longer need to pretend that capitalism is inextricably tied to democracy. The new millennium revealed that the aspirations for expansive democracy and despotic, kleptocratic capitalism are bound together around new technologies and contradictory drives for economic expansion. Eight people now control as much wealth as the poorest 50 per cent. 'Poverty' declines but deprivation grows. It seems the Cylons have already attacked!

Debord theorized in 1988 that the former world of two spectacles, diffuse (Keynesianism) and concentrated (East Bloc State Capitalism), had given way to the integrated spectacle. 'The emergence of this new form is attributable to a number of shared historical features', Debord specifies, 'namely, the important role of the Stalinist party and unions in political and intellectual life, a weak democratic tradition, the long monopoly of power enjoyed by a single party of government, and the need to eliminate an unexpected upsurge in revolutionary activity' (Debord 2011, 8-9). He goes on to summarize that this new spectacle entails five features: 'incessant technological renewal; integration of state 
and economy; generalized secrecy, unanswerable lies; an eternal present' (2011, 11-12). Where spy agencies use their leverage in international trade and hack into SIM Card manufacturers, struggles for this 'twilight world' rage beneath and within the smooth appearance of circulation. What is, in essence, a violent autocratic rule in the name of the market economy has spread like mould across the world's development, corrupting or murdering revolutionary alternatives.

Here, we must not conflate our apocalyptic fantasies with machines themselves. Instead, Debord would have us reclaim the historical project of the dissolution of class society. This requires encoding a consciousness that would never program the spectacle's waste of life, its mathematics of obsolescence, and surplus populations. Instead, this consciousness must encode maximal life, and expansive solidarities. Haraway assembles oppressed traditions within an ancient-futuristic 'Cyborg writing', which 'must not be about the Fall, the imagination of a once-upon-a-time wholeness before language, before writing, before Man. Cyborg writing is about the power to survive, not on the basis of original innocence, but on the basis of seizing the tools to mark the world that marked them as other' $(1991,175)$. Perhaps this is more than solidarity; perhaps it is life itself. Haraway continues, '[w] have all been colonized by those origin myths, with their longing for fulfilment in apocalypse...Feminist cyborg stories have the task of recoding communication and intelligence to subvert command and control' $(1991,175)$. To resist the new integrated spectacle we must decode all command and control, particularly those apocalyptic, autocratic, and scarcity-based uses of life, relegating it to survival (or worse), and subordinating it to the pseudonature of capital's self-expansion. Debord expounds, 'Consciousness of desire and the desire for consciousness together and indissolubly constitute that project which in its negative form has as its goal the abolition of classes and the direct possession by the workers of every aspect of their activity' (\#53). ${ }^{16}$ Debord's manifesto is in fact a call for practice, suggesting that this practical abolition happens in the mythic 'workers councils', 'which must internationally supplant all other power, the proletarian movement is its own product and this product is the producer himself' (\#117). In his formulation, the end of the autonomous movement of non-life occurs when social activity has itself as its product, not money and exchange-value. So, how?

\section{Cylon Troll in the Revolutionary Council}

Microsoft founder, Bill Gates recently caused a stir by suggesting that we tax robots. Gates, like many, has noticed that despite easing the creation of material wealth, machines within capitalism increase worker productivity and decrease the need for (and cost of) workers. Opponents have suggested that Gates' plan would hinder productivity, confining the economic trickle down of the new robotic age and limiting its benefits. What is striking about Gates' plan and 
various other plans, like the universal minimum wage, is that they have yet to fathom a socially exuberant way of un-mediating life, creativity, free time, idleness, reading 'unproductive' books, or listening to music beyond wagelabour and its forms of 'augmented survival'. Sure, we cannot accomplish everything at once. Nevertheless, Debord's radical manifesto, through his emphasis on capital's 'autonomous movement', always keeps us looking forward and, hopefully, wary of dead ends, false flags, and snares. For those pitfalls, Lyotard and many others stabbed at the Marxist project after the failed revolutions of 1968, because 'everywhere, the Critique of political economy (the subtitle of Marx's Capital) and its correlate, the critique of alienated society, [were being] used in one way or another as aids in programming the system' $(1984,13)$. Instead, Debord's writing is interested in holistic freedom, in revolution against the obedience of life to its own products, and against hierarchical society. 'No quantitative relief of its poverty, no illusory hierarchical incorporation', Debord exclaims, 'can supply a lasting cure for its dissatisfaction, for the proletariat cannot truly recognize itself in any particular wrong it has suffered...but only in the righting of the unqualified wrong...the universal wrong of its exclusion from life' (\#114). In the Councils, Debord sees society becoming the subject of its own history, with itself and its world as its product, transforming 'existing conditions in their entirety' (\#74, \#75, \#179).

But, twenty years later Debord also warns us, 'the highest ambition of the integrated spectacle is still to turn secret agents into revolutionaries, and revolutionaries into secret agents' $(2011,11)$. By the late-1980s, having caught glimpses of shadow governments engaging in anti-communist warfare through Iran-Contra (US) and the clandestine intrigue of the 'Years of Lead' (Italy), Debord had a considerably more cautious outlook by the end of his life. Fascism has always benefited from its false flags, through its populist infiltration of the 'masses' striving to 'eliminate the property structure' (Benjamin 1968, 241), utilizing the language of socialism, and aestheticizing class frustration. The concentrated spectacle's purges and authoritarian betrayal of the revolution and the diffused spectacle's business unionism represent an infiltration of a metaphorical 'workers council'. After the roll out of neoliberalism, Operation Condor, Iran-Contra, the Telecommunications Act of 1996, Bayer's merger with Monsanto, and the election of a tax dodging reality TV character favoured by white nationalists for US president, we have many reasons to do more than worry about a Cylon troll infiltrating Debord's hopeful form for social liberation. 'Our society is built on secrecy, from the 'front' organizations which draw an impenetrable screen over the concentrated wealth of their members, to the 'official secrets' which allow the state a vast field of operation free from any legal constraint,' Debord warns $(2011,52)$. But perhaps it is the transparency and dialogue of the Councils, the antithesis of secrets that still offers us hope? If so, and in this digital epoch, it will need guards against bots and avatars that still aim for autocracy, hierarchy, extinction, and the autonomous movement of non-life in all its forms. 


\section{Notes}

${ }^{1}$ Quoting Revelations: ['These have one mind, and shall give their power and strength unto the beast.' Revelations, 17:13; 'And that no man might buy or sell, save he that had the mark, or the name of the beast, or the number of his name.' Revelations, 13:17.]

${ }^{2}$ Cylons are a race of robots, produced by a race of now-extinct lizard people, are key antagonists in the 1978 TV show, Battlestar Galactica, at war with the several colonies of humans.

${ }^{3}$ E.g., Investor's Business Daily (2016).

${ }^{4}$ See Marcuse (1991) and Sen (2000) for different approaches to a concept that shares a great deal with Debord's critique.

${ }^{5}$ In the former, the human is still central-machines function in relation to human activity-as opposed to the post-human evolutionary fantasies of the latter.

${ }^{6}$ See Rosati (2012) for a more detailed discussion in a different context.

${ }^{7}$ Durham and Kellner interpret: 'Consumers of the spectacle, Debord argues, are separated from the process of production of everyday life, lost in consumerist fantasies, media phantasmagoria, and in our day the transformative media of cyberspace and computer technology. 'Real life' is unreal, unglamorous, and boring in this world, while the spectacle is exciting and enthralling' (2006: 93).

${ }^{8}$ Or just using us as batteries, as in the Matrix.

${ }^{9}$ Similar examples abound in the Cultural Studies Reader, as just one example.

${ }^{10}$ I have excluded the last sentence to focus on one concept at a time.

${ }^{11}$ Lack of space keeps me from specifying in detail the key circuits of which these moments are a part.

${ }_{12}$ This is similar to new, disastrous water privatization projects and to pay-forfaster-service schemes in amusement parks, airports, and the Capital Beltway.

${ }^{13}$ See Loftus (2006) for an analogous example in the privatization of water.

${ }^{14}$ As Horkheimer and Adorno note, 'The relentless unity of the culture industry bears witness to the emergent unity of politics' $(2007,96)$.

${ }^{15}$ Like the myth of Sapiens murdering Neanderthalensis, rather than interbreeding.

${ }^{16}$ We might now replace 'workers' with 'multitude' or maximalist categories not at risk of productivist chauvinisms.

\section{References}

Andrejevic, Mark. 2003. Reality TV: The Work of Being Watched. Lanham, MD: Rowman \& Littlefield Publishers.

Andrejevic, Mark. 2013. 'Exploitation in the Data Mine.' In Internet and Surveillance: The Challenges of Web 2.0 and Social Media, eds. Fuchs, Christian, 
Kees Boersma, Anders Albrechtslund, and Marisol Sandoval. NY: Routledge , pp. 71-88.

Baudrillard, Jean. 1994. Simulacra and Simulation. Translated by Sheila Faria Glaser. First Edition, 17th printing. Ann Arbor: University of Michigan Press.

Benjamin, Walter. [1936] 1968. 'The Work of Art in the Age of Mechanical Reproduction' In Hannah Arendt (ed.), Illuminations. New York: Schocken Books.

Birkbeck, Chris. 1978. 'Self-Employed Proletarians in an Informal Factory: The Case of Cali's Garbage Dump.' World Development 6 (9): 1173-85.

CNET. 2017. 'Why India Snubbed Facebook's Free Internet Offer.' Accessed March 9. https://www.cnet.com/news/why-india-doesnt-want-free-basics/. CNET. 2017. 'Google's Magic Internet Balloons Bringing Wi-Fi to India.' Accessed March 9. https://www.cnet.com/news/googles-magic-internetballoons-bringing-wi-fi-to-india/.

Crawford, Susan. 2013. Captive Audience: The Telecom Industry and Monopoly Power in the New Gilded Age. New Haven Conn.: Yale University Press.

Debord, Guy. 1995. The Society of the Spectacle. Translated by Donald NicholsonSmith. Revised ed. edition. New York: Zone Books.

Debord, Guy. 2011. Comments on the Society of the Spectacle. $3^{\text {rd }}$ edition. London; New York: Verso.

Deleon, Abraham P., and E. Wayne Ross. 2010. Critical Theories, Radical Pedagogies, and Social Education: New Perspectives for Social Studies Education. Rotterdam; Boston: Sense Publishers.

Durham, Meenakshi Gigi, and Douglas M. Kellner, eds. 2012. Media and Cultural Studies: Keyworks. Malden: Wiley Blackwell.

During, Simon, ed. 2007. The Cultural Studies Reader. $3^{\text {rd }}$ edition. London; New York: Routledge.

Eubanks, Ralph. 2015. 'The Land That the Internet Era Forgot'. WIRED. November 7. https://www.wired.com/2015/11/the-land-that-the-internet-forgot/.

Federal Communications Commission. 2011. 'Open Internet.' January 12. https://www.fcc.gov/general/open-internet.

Gilbert, Melissa R. and Masucci, Michelle 2011 Information and Communication Technology Geographies: Strategies for Bridging the Digital Divide (e-Book), British Columbia: Praxis (e)Press

Hamill, Jasper. 2016. 'Apocalyptic War between Robots and Humans Set to Erupt in next 25 YEARS.' Mirror. January 7. http://www.mirror.co.uk/news/technologyscience/technology/robots-declare-war-humans-within-7132162.

Haraway, Donna. 1991. Simians, Cyborgs, and Women: The Reinvention of Nature. $1^{\text {st }}$ Edition. New York: Routledge.

Hardt, Michael, and Antonio Negri. 2011. Commonwealth. Cambridge (USA); London: Belknap.

Harvey, David. [1982] 2007a. The Limits to Capital. Updated edition. London, New York: Verso. 
Hawking, Stephen, et al. 2014. The Independent. 'Steven Hawking: “Are We Taking Artificial Intelligence Seriously." May 1. http://www.independent.co.uk/ news/science/stephen-hawking-transcendence-looks-at-the-implicationsof-artificial-intelligence-but-are-we-taking-9313474.html.

Holt, Jennifer. 2011. Empires of Entertainment: Media Industries and the Politics of Deregulation, 1980-1996. New Brunswick, N.J: Rutgers University Press.

Horkheimer, Max, and Theodor W. Adorno. 2007a. Dialectic of Enlightenment. Edited by Gunzelin Schmid Noerr. Translated by Edmund Jephcott. 1st edition. Stanford, CA: Stanford University Press.

Independent. 2016. 'Generals Warn War with Russia Would Be 'Extremely Lethal.” http://www.independent.co.uk/news/world/future-war-russiachina-us-extremely-lethal-fast-artificial-intelligence-cyber-warfarea7347591.html.

Investor's Business Daily. 2016. 'AI Meets ROI: Where Artificial Intelligence Is Already Smart Business.' March 10. http://www.investors.com/news/ technology/artificial-intelligence-weaves-its-way-deeper-into-dailybusiness/.

Jappe, Anselm, and T. J. Clark. 1999. Guy Debord. Berkeley, CA: University of California Press.

Lenin, V. I. 1969. Imperialism, the Highest Stage of Capitalism: A Popular Outline. New York: International Publishers.

Loftus, Alex. 2006. 'Reification and the Dictatorship of the Water Meter'. Antipode 38 (5): 1023-45. DOI: https://doi.org/10.1111/j.1467-8330.2006.00491.x.

Lowrey, Annie. 2017. 'The Future of Not Working.' The New York Times, February 23. https://www.nytimes.com/2017/02/23/magazine/universalincome-global-inequality.html.

Lukács, Georg. 1972. History and Class Consciousness: Studies in Marxist Dialectics. MIT Press edition. Cambridge, Mass: The MIT Press.

Manjoo, Farhad, and Kathryn Bowers. 'Will Robots Steal Your Job?' Slate, September 30, 2011. http://www.slate.com/articles/technology/robot_ invasion/2011/09/robot_invasion_can_computers_replace_scientists_html.

Marcuse, Herbert. 1991. One-Dimensional Man: Studies in the Ideology of Advanced Industrial Society. Boston: Beacon Press.

Marx, Karl. 1992. Capital: Volume 1: A Critique of Political Economy. Translated by Ben Fowkes. Reprint edition. London, New York, NY: Penguin Classics.

Marx, Karl. 1993. Capital: A Critique of Political Economy, Vol. 3. Translated by David Fernbach. Reissue edition. New York, NY: Penguin Classics.

Marx, Karl, and Frederick Engels. 1975. Marx \& Engels Collected Works Vol 03. Lawrence \& Wishart. https://muse-jhu-edu.ezproxy.bgsu.edu:9443/ book/32873.

Mitchell, Katharyne, and Matthew Sparke. 2016. 'The New Washington Consensus: Millennial Philanthropy and the Making of Global Market Subjects.' Antipode 48 (3): 724-49. 
Politifact.com. 2017. 'Yes, Global Poverty Fell Dramatically after 1990'. Accessed March 9. http://www.politifact.com/global-news/statements/2017/mar/01/ boris-johnson/yes-global-poverty-fell-dramatically-after-1990/.

Rosati, Clayton. 2012. 'Guy Debord, 'Gilded Poverty', and the Contemporary Crisis: On Marxism, Spectacle, and the Banality of Inequality.' Culture, Theory and Critique 53 (3): 339-63. DOI: https://doi.org/10.1080/14735784.2012. 721626.

Sen, Amartya. 2000. Development as Freedom. New York:Anchor.

Sunstein, Cass R. 2017. \#Republic: Divided Democracy in the Age of Social Media. Princeton: Princeton University Press.

Thatcher, Jim, David O'Sullivan and Dillon Mahmoudi. 2016. 'Data Colonialism through Accumulation by Dispossession: New Metaphors for Daily Data.' Environment and Planning D: Society and Space 34 (6): 990-1006.

Townsend, Anthony M. 2003. 'Wired / unwired: The Urban Geography of Digital Networks.' Unpublished Dissertation. MIT, Department of Urban Studies and Regional Planning.

Wagstaff, Keith. 2016. 'What If the Robot Utopia Leads to an Existential Crisis for Humans?' Motherboard. April 25. https://motherboard.vice.com/en_us/ article/what-if-the-robot-utopia-leads-to-an-existential-crisis-for-humans.

Walker, Benjamen. 2012. 'The Big Ideas Podcast: Guy Debord's "Society of the Spectacle." The Guardian, March 28, sec. Opinion. https://www.theguardian. com/commentisfree/audio/2012/mar/28/big-ideas-podcast-debord-societyspectacle. 
